Article

\title{
The Role of Trust in Sustainable Heritage Management Networks. Case Study of Selected Cultural Routes in Poland
}

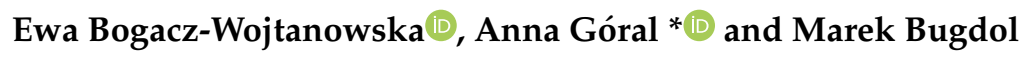 \\ Faculty of Management and Social Communication, Jagiellonian University, 4 Łojasiewicza Street, 30-348 \\ Cracow, Poland; ewa.bogacz-wojtanowska@uj.edu.pl (E.B.-W.); marek.bugdol@uj.edu.pl (M.B.) \\ * Correspondence: anna.goral@uj.edu.pl
}

Received: 19 March 2019; Accepted: 9 May 2019; Published: 18 May 2019

check for updates

\begin{abstract}
Currently, the most common way of managing cultural heritage in a sustainable manner takes the form of cultural routes. The phenomenon of cultural routes mainly results from their innovative organisation, different from the previously adopted institutionalised and formalised heritage management structure that did not align with the contemporary discourse around cultural heritage, which currently constitutes one of the bases of sustainable development. The novel idea focuses on the active involvement of many diverse entities in heritage management: not only public sector organisations with their statutory appointment for this purpose, but, first and foremost, entrepreneurs who create heritage products, tourists visiting sites on the route, or people who create this heritage. Thus, the cultural route acquires the characteristics of a network-points (nodes) that are shaped depending on the needs of the region and its inhabitants, their knowledge, experience, current ideas about a given place, and the way in which specific communities would like to be perceived. The undertaken research problem explores what features cultural route networks have and how they are managed, as well as what values, including trust, are manifested in the mutual relations of route-related entities. An original concept of shaping trust within the network of cultural routes has also been proposed based on the research results.
\end{abstract}

Keywords: cultural routes; trust; cooperation networks; cultural heritage management

\section{Introduction}

Culture as the basis of social life is considered to be one of the four pillars of sustainable development [1-4]. One of the major elements of culture is cultural heritage, which is understood not only as a collection of monuments and other products of human activity, but also as a carrier of values that are important for specific social groups, a source of building local and collective identity, as well as a sense of belonging [5-7]. Currently, more and more organizations operating on various levels (international, national, and local) undertake activities for the benefit of cultural heritage, primarily in the area of conservation and the sustainable use of resources [8,9].

One of the tools supporting the preservation of the cultural heritage and sustainable development of the areas connected with it is the cultural route. The cultural route is a mapped out and marked material route, which connects heritage organisations, sites, and places that are selected according to a set thematic criterion, which constitute a unique and representative example illustrating the broadly understood cultural heritage of a region, community, ethnic group, minority, or nation $[7,10]$. Through the presentation of the material heritage, the route enables discovering, understanding, and popularising the intangible heritage, which treats both of these areas as an inseparable whole [11]. Nowadays, cultural routes are considered as an important step in the development of the concept of cultural heritage and in the recognition of its diversity [12]. 
Cultural routes, being understood as an idea, a public policy tool, and a form of inter-organisational collaboration, have been spreading across the world since the 1980s, especially in Europe, where the route trails cross practically all European cities and regions. Cultural routes are mostly considered in the context of the functions and competences of routes [10], particularly in the aspect of geographical space; the importance of local, regional, and transnational tourism for the sustainable development [13-15]; the area of cultural, social, and civic activity [8,16]; ways of understanding routes in local communities [17]; the promotion of sustainable tourism development, including cultural tourism [18]; and, sustainable development of infrastructure [19]. Cultural routes are also considered as a priceless element of cultural heritage [20], not only because, once destroyed, it can never be reconstructed, but above all due to the role that it plays for particular individuals and their communities. However, much less frequently, they are subject to an analysis from the organisational and management point of view. The research refers mainly to the engagement of stakeholders [21,22], principles of effective management [22,23], certification, and evaluation of the effectiveness of cultural routes in local communities [21,24]. There are also studies raising the issue of cultural routes as a network of collaboration between various entities, which create network structures and network management methods [22,25]. These studies enabled the identification of a clear research gap in the area of the features of route networks, in particular with regard to the shared values that connect the entities-elements of the route network. This is why the undertaken research problem explores what features cultural route networks have and what methods are used to manage them, as well as what values, including trust, are manifested in the mutual relations of route entities. Based on the research results, we have also proposed an original concept of shaping trust within the network of cultural routes. Tackling this problem is important from the perspective of sustainable development of local and regional communities, where cultural heritage and its organisation in the form of cultural routes is one of the significant elements of economy, tourism, and shaping of the local identity [15]. Moreover, heritage and cultural routes remain the bases of sustainable development that are still relatively empirically unexplored. The recognized scientific discourse is mainly theoretical and there is a lack of research demonstrating what sustainable management of a cultural route looks like in practice.

What is important from the point of view of the discussion that is presented in this article, in their disputes, contemporary heritage theoreticians with increasing frequency evoke the necessity of adopting an integrated approach to the issue of cultural heritage, departing from perceiving this issue through the prism of specific structures and mainly focusing on the social and economic impact of such resources on regions' development and looking closely at the ecosystems that they create $[25,26]$. Therefore, when designing the research that is presented in this article, we assumed that the reflection on the phenomenon of heritage requires looking at it through the lens of its function in local communities, and the ways in which it is used (intentionally or not) in shaping the social and economic development of these communities. This is also the reason why, in order to more closely examine the role of trust in sustainable heritage management on the example of cultural routes, it was necessary to draw from various academic disciplines: heritage studies, tourism studies, and trust research. Crucial in our considerations was adopting as a point of departure the assumption of the existence of significant interrelations between three fundamental pillars of heritage: its creators, producers, and recipients, who interact with one another at all stages of the cultural heritage process [27]. Thus, the environment of cultural routes was described as "complex, immersed in the dynamic climate of interconnections that shape relations between heritage creators, producers, and recipients" [27]. This assumption allowed for us to create a model showcasing the theoretical connection between the fields of study applied in the conducted analysis. The centre of this model comprised of people and particular artefacts that represented their cultural heritage. These people share specific values that constitute a base for forming bonds and networks aiming at the use of heritage for the development of local communities-in their social, cultural, and economic dimension. Particular attention was devoted to the issue of trust as a foundation of the sustainable management of this resource. 
The article consists of the following parts: a theoretical introduction, covering the state of research in the field of cultural heritage, cultural routes in reference to sustainable development, as well as trust in networks. Subsequently, we present the methodology of the research that was conducted among Polish cultural routes and its results. Whereas, the summary constitutes a description of original concept research on trust within the network of entities creating routes.

\section{Theoretical Background}

\subsection{Cultural Routes as a Method of Sustainable Heritage Organisation and Management}

\subsubsection{Sustainable Development in Reference to Cultural Heritage}

Recent decades have illustrated researchers' growing interest in cultural heritage and its role in shaping the surrounding reality, both social and economic [8]. In addition to art historians, humanistic geography has also contributed to the study of cultural heritage. Reflecting on the "essence of the place", Yi-Fu Tuan, Edward Relph, and Anne Buttimer place a human being regarded in the context of regional culture and its heritage in the centre of their interests [28-30]. In this approach, researchers perceive cultural heritage primarily as an expression of the human culture and humans' relationship with the place where they operate [31]. Laurajane Smith emphasises that heritage, as a place or places of heritage, cannot be seen only as a representation of the past, but also as places or sites that influence the current experiences and perception of the world by people. Thus, cultural heritage can be treated as an element that influences the sense of cultural identity and belonging of particular individuals or groups [17]. Cultural identity should be understood as collective self-awareness embodied and reflected by a specific group in relation to a physical environment and territory, such a group inhabits. Cultural heritage is crucial for maintaining and transferring cultural identity to future generations [32]; it constitutes the source of pride and belonging and an identifying and distinguishing feature [33]. The foundation of cultural identity, which is also connected to cultural heritage, is memory as an element of the bond between members of the group, as well as social memory, being deeply rooted in the local history, which, in turn, enables setting apart a place that is inhabited by a given group or community [34,35].

Cultural heritage is also increasingly the subject of interest of economists and representatives of management sciences who see it as an important resource from the perspective of stimulating the sustainable economic development of regions $[8,9,16,36]$. The aim is to develop sources of development alternative to traditional sectors of the economy, while taking into account the free development of production and creativity of their residents [36], which is in accordance with the concept of sustainable development. In a broader sense, culture is regarded as one of the four pillars of sustainable development, alongside other social domains: ecology, economics, and politics [2]. As a pillar of sustainable development, three main functions of culture are considered [11]. In the first one, which can be called "culture in sustainable development" [37], it plays the supporting and self-regulating role; it is a natural capital that should be protected and evenly distributed among generations [38]. In this regard, as the fourth pillar of sustainable development, culture is tangible, material, and functionally oriented [37,38]. Within its second function, as "culture for sustainable development", it has both material and intangible dimension and it constitutes the framework, the context and the counterbalance for the remaining three pillars of sustainable development [37]. Finally, the third function, "culture as sustainable development", is where culture constitutes the foundation of sustainable development that coordinates and integrates activities within this area, or rather the intangible dimension that refers to the basic principles, beliefs, and values.

Within the framework of sustainable development, one also notices the economic potential that results from the growing consumption of cultural heritage goods and services-especially in the promotion of space (territorial marketing), cultural tourism development, and economic development: the creation of new jobs, mainly in the tourism and creative services sectors, the increase in revenues of local entrepreneurs, and a general impact on the GDP [8,39-41]. The multiplicity of stakeholders that are 
involved in the processes of creating and managing cultural heritage resources is also emphasised [42]. The research also pertains to the ways of organising heritage and organisational and management structures that will ensure the development of heritage-related places [43-45].

It is worth noting that, in recent years, researchers and practitioners of cultural heritage have created a discourse that perceives cultural heritage as a significant contribution to wider activities also in the creation of sustainable societies [5]. The concept of sustainable development as regards the cultural heritage also refers to the issue of local identity, where cultural heritage plays a fundamental role in the processes of creating a sense of belonging and a "sense of place" in a globalising social reality [46]. Cultural heritage is not only of value to people who own it or live in historical real estate; it can be equally valuable for the prosperity and quality of life of the community, and it can also help to mitigate the effects of cultural globalization and become an incentive for sustainable development $[46,47]$.

\subsubsection{Cultural Routes as an Example of Sustainable Heritage Management}

Contemporary heritage theorists evoke the need to adopt an integrated approach to the issue of cultural heritage, focusing on its social and economic impact on the sustainable development of regions and examining the networks and ecosystems that they create [25-27]. In the course of these reflections, the idea of cultural routes was born, at first as a local grassroots initiative that, in time, grew to an international scale. According to the most classic definition, as proposed by the European Institute of Cultural Routes, the route is: "physically marked and characterised by having its own historical dynamics and [ ... ] functions, showing the development of humanity as a multidimensional and continuous exchange of goods, ideas, knowledge and values within countries and regions, as well as between them for significant periods of time, causing mutual interaction of cultures in space and time, which is reflected in the material and immaterial heritage" [48]. The concept of cultural routes significantly differs from the broader notion of tourist routes, previously existing in the literature. Tourist routes are usually “(...) routes included in the general transportation network, used for tourist traffic between regions or tourist destinations" [49]. A tourist route consists of "a marked sequence of tourist sites located along open public routs on which tourists travel on their own or by means of public transport", or it can be "a trail or path leading through an attractive touristic areas, sites, adapted to various forms of tourism" [49]. Unlike cultural routes, the main objective of creating tourist routes can be described as recreational, and tourists are their main target.

The International Committee on Cultural Routes, among the key components of the cultural route, points to the context, contents, and cultural significance, where the context refers to the space in which the route operates, and the content to the material objects that constitute the route's anchor points and, at the same time, are a testimony to the cultural richness of the region. Researchers emphasise such features of the route as its constant recreation and rooting in memory and tradition, which obviously draws attention to the role of local communities in the functioning of routes $[14,43,50,51]$. The cultural route recognises and emphasises the value of all its constituent entities as significant parts of the whole. It also helps to illustrate the contemporary social concept and the value of cultural heritage as a resource for sustainable social and economic development $[10,23]$. By treating the cultural route as a compilation of dynamic elements of cultural communication, its cultural heritage values may be appreciated in their real spatial and historical dimension, which allows for a comprehensive and balanced approach to the preservation of the entire route [21].

Despite the fact that the concept of cultural routes refers to the social and cultural development of local communities, they are also regarded as tourist products [8,38]. Directing attention towards the economic dimension of heritage and cultural routes, as related to the development of tourism, emerge from the search for sources of the local development of cities and regions as an alternative to traditional sectors of the economy [36]. For this reason, analyses of cultural routes often emphasize their role in economic development, which often dominates the discussion on a cultural routes' value $[14,38]$. Such an approach to cultural routes frequently leads to the commercialisation of this heritage product, as 
evidenced by the example of pilgrimage, literature-, or film-themed routes, which shifts the focus of a route's value from its social to a purely economic dimension, which overlooks the role of local communities in their functioning. However, it should be noted that, when discussing tourism on cultural routes, researchers [14] (p. 514) emphasise that "Whatever the scale, the essence of itineraries is that they combine the opportunity for cultural consumption with points of sale of goods and services functioning around such culture and inextricably linked to it. As with the link between the historic sites and tourism in general, they encourage to continuously re-image places treating them as a kind of inspiration for development arising from nostalgia, memory and tradition related to places on the route". Although, in their discussions, these academics underline the clear impact of routes on the development of tourism, they also highlight their vital role in w constant re-imaging of the places, having roots in memory and tradition, which obviously draws our attention to the role of people, and especially of local communities, in routes' functioning. This is why, it is important to note the people who co-create them and values they share in the process of examining the functioning of cultural routes. Consequently, the main idea of the research that is presented in this paper was to depart from only perceiving a route as a tourism product, thus considering it in terms of the regional economy, but to treat it as an important site that influences (and is influenced by) local communities, in line with the conviction that the main reference group for route functioning are the people who are constantly in its immediate vicinity (inhabitants) and not entities that sporadically appear within its area, sometimes only once (tourists), though the latter cannot be left out when discussing routes either.

The approach to the route as a certain organisational structure of heritage shifts the centre of gravity in the discussion about the route from the material resources that it comprises (e.g., churches, palaces) to the people present-in various capacities-on the route, relations between them, and the values they share. Cultural routes offer their users a new model of co-creation and participation in culture, which often also constitutes a specific anchor point for understanding their identity and shaping the future, thus becoming a space for cultural, social, and civic activities [8,51]. In this way, it becomes primarily a space, a special binding agent of the ecosystem that is created by the local community, which gives it meaning through its activity.

The phenomenon of cultural routes is connected not only with a new view of heritage itself, but it is primarily the result of their innovative organisation, being different from the previously adopted institutionalised and formalised heritage management structure [23]. As heritage seems to be a cultural creation of extraordinary complexity, which is shaped by the relationship between creators, producers, and recipients of heritage [27], it requires the active involvement of many different entities in its management: not only public sector organisations with their statutory appointment for this purpose, but, first and foremost, entrepreneurs who create heritage products, tourists visiting sites on the route, or people who create this heritage [23]. When this approach to the organisation of the route is adopted, a cultural route acquires the characteristics of a network-points (nodes) shaped, depending on the needs of the region and its inhabitants, their knowledge, experience, current ideas about a given place, and the way in which specific communities would like to be perceived. These features relate not only to the form of the trail, but also to the content that it conveys [51].

The presented view on heritage management allows for one to look at the values that form the basis of the routes' functioning. The basic premise of this study was to treat the route as a network structure that is formulated by a wide group of its participants and stakeholders, in accordance with the belief that the basic reference group for the functioning of the route comprises those who remain in its immediate environment (residents) and, rarely, entities appearing in its area occasionally, and sometimes only once (tourists). An important reference point was also the research that was conducted by Bogacz-Wojtanowska and Góral [25], which showed that the structures that were adopted by cultural routes vary, starting from network relations that are fragmentary and under development, to very loose, bottom-up networks, to formalised and hierarchical permanent sites. In their research, Bogacz-Wojtanowska and Góral [25] emphasised that the type of the adopted route structure (loose, built at the grassroots level on the basis of relations between people, or more formalised, with top-down 
construction and management) has a significant impact on how a route is organised and how it develops. Looser structures create more space for the activities of people who form the routes; more autonomy generated by such sites favours the genuine involvement of people in their development. In turn, more formalised structures, even though they are better at organising their internal relations and the manner in which a route operates, contribute in a natural way to the decrease in engagement and initiative of people who form a route in favour of the management, which, in the long run, may be contrary to the very idea of cultural heritage.

\subsection{Trust in Networks}

From the research that is been conducted so far [25], it follows that tourist routes are network-based and values have an important role in their operation. Routes are a network structure that is supported top-down by the public sector [52]. Trust plays an important role among many organisational values [53]; therefore, when examining routes, one should pay attention to the role of trust in the networks.

\subsubsection{The Concept of Trust}

In the literature trust is defined as: an expectation as to the outcome of interactions [54], an organisational resource [55], a state expressing positive expectations regarding the motives of other people's behaviour [56], a psychological state [57], readiness to accept the behaviour of the other side [58], an element of social capital [59], the foundation of social interactions in the organisation [60], and a bet on the future and uncertain actions of other people [61], a critical factor for each system that is built on community, cooperation, and competition [62]. The conducted review of the existing definitions allows us for concluding that trust is:

- $\quad$ one of the elements of social capital (alongside norms and values),

- the foundation of social interactions (it allows for cooperation and implementation of common goals, enables the development of social ties, new contacts, and business endeavours),

- the organization's resource (located in accordance with the process approach at the entry and exit of social processes, conducive to the processes of economic and social exchange), and

- expectation of individuals and groups towards the behaviour of other people or groups.

Trust is very important in maintaining heritage management networks, because, not only can it promote collaboration between many different entities and make economic exchange more efficient, but it can also mitigate the risk and reduce various costs [63]. It should be remembered that trust depends on risk - if the results of the actions undertaken were known, then trust would be unnecessary. "Trust is a critical factor for each system built on community, cooperation, and competition", and this is precisely the situation of the studied entities, i.e., cultural routes in Poland [62]. Trust fosters economic development [64] and it has colossal importance in maintaining positive relations in a group of people who are trying to do something positive together [65].

Additionally, the existing dependencies occurring between entities that form tourist routes explicitly indicate the need to apply the doctrine of sustainable development. The notion of justice is vital for this doctrine [66], and it should be remembered that this value is universally accepted as the basis of trust. The relationship between sustainable development and trust results, i.a. from the fact that sustainable development requires the cooperation of many political, economic, and social partners, and solutions are therefore needed to improve trust in partnership [67]. Trust is also of great importance for shaping and maintaining sustainable behaviour [68].

Moreover, the role of trust in decision-making processes and the fact that trust influences the sustainability of a professional learning community is observed [69]. Trust is also important in the development of competencies that are conducive to undertaking sustainable development activities [70]. Sustainability is strongly influenced by broad environmental changes, requiring trust, and self-reflection [71]. 
Trust shall be understood as an element of the value system while taking into account the purpose of the paper and research objectives,-alongside the sense of community and identity, justice, and engagement. By the same token, we acknowledge that, according to systemic theory, all of the values are interdependent and interact with one another. A value is an object of desires that seem to be good in itself [72].

\subsubsection{Trust in the Network}

Networks can be considered to be organisations with a special need for trust [73]. High social trust can foster a dense social network, which can facilitate information sharing [74].

From the point of view of the practice of conducting business activities, the issue of developing trust in social and economic networks is nothing new. For a long time, business people have been using such networks and building trust, for example, to support commerce during the American War of Independence. Using business books by Daniel Eccleston from Lancaster, covering the period from January 1780 to December 1781, Downs, Carolyn [75] showed how he had taken advantage of trust-building activities and created open networks in Great Britain and the West Indies, with a view of developing, maintaining, and diversifying his business [75].

In the recent period, research into issues related to networks and trust has focused on the following: trust in governance network [76], gender-based differences in risky environments [77], the significance of the various dimensions of trust (abilities, kindliness, integrity, and predictability) in the particular phases of the trust building process [78], the significance of the various dimensions of trust in developing and managing interpersonal trust [79], the significance of network infrastructure in information markets and products [80], trust and reliability in Online Social Networks [81], the importance of the kinds of actors in building trust in networks that are created in the public sector [82], relations between the level of social support experienced by network members and the level of trust available to network members with respect to one another and with respect to the network as a whole [83], the influence of trust and social networks on wellbeing-in the relationship between social capital and income [84], the level of trust in cliques [85], expectations regarding reliability [86], the role of trust in interactions in complex social systems [87], the significance of a network of trust in career progression [88], the significance of trust in e-commerce services [89], the uses of social media in the process of managing and building trust [90], the significance of the independent thought and readiness for change in creating informal social networks [91], and the role of network openness and social capital in the information sharing process [92].

Consequently, current research on the issue of trust in networks focus on the following:

- the role of trust among network actors and participants in the building and maintenance of a network,

- the role and significance of networks in the building of trust-its complexity, structure and strength, and

- the significance of trust and networks themselves in various management processes.

\subsubsection{Trust and Social Networks in Tourism}

A separate but related body of research comprises studies exploring the significance of trust and social networks in tourism. Yvonne von Friedrichs Grangsjo, Evert Gummesson [93] and N. Agheorghiesei and V. Nita [94] also emphasised the need for building trust as an element of social capital and involvement in activities. The conducted research showed how trust among emigrants in another country developed in social networks [95]. It was proposed that social groups should invest in strengthening social ties, developing the abilities of local institutions, diversifying tourist products, and controlling the development of infrastructure [96]. Various analyses covered factors that affect the attitude of local authorities of tourist destinations towards sustainable planning tools in a networking context and they have indicated that more cognitive-related variables (such as prior 
expertise, purposive benefits, and learning) seem to be more important than more affective-related variables (such as entertainment, trust, identification, and relations with network promoters) [97]. The research revealed tension among various entities that are involved in urban tourism. While the involvement of small local enterprises is beneficial, they are restricted in their actions by conflicts of interest, the lack of trust, limited social networks, and poor involvement in urban communities [98].

It was found that trust was of great importance in driving virtual network business relationships among economic agents towards mutually satisfactory, fair, and ethical behaviours. It was explained how virtual network relationships among newcomers and partners were formed and maintained their trust beliefs regarding the companies that they dealt with in network relationships [99,100]. Another conclusion was that the level of social capital that was held by leading tourist centres was not high and that there were no considerable differences among the leading tourist centres with respect to social capital [101]. The research that was conducted in Poland has focused, to a considerable extent, on trust as a component of social capital [102-104]. W. Czakon and K. Czernek [105], as well as W. Czakon together with P. Klimas [106], among other scholars, conducted interesting research into trust. J. Kosmaczewska found that a high level of trust created opportunities for flattening organisational structures, e.g., in business entities providing tourist services and for reducing transaction costs [104]. A. Balińska researched network tourist products in rural areas [102]. K. Czernek dealt with an interesting problem of social rootedness and found that it favoured "the building of trust in its cognitive and affective dimensions, which, in turn, supports the initiation, development, and effects of cooperation in the tourist sector" [103] (p. 199). The research that was conducted by W. Czakon and K. Czernek indicated that "transference by third-party legitimisation and reputation in the network play a vital role in the decision to enter into network coopetition. Inversely, calculative, capability-based and intention-based trust are shown to be difficult to develop and are rarely used" [105] (p. 64). W. Czakon, together with P. Klimas, analysed the three dimensions of the climate of interorganisational cooperation (trust, inclination towards cooperation, and experience in cooperation). Their results confirm the peculiarity of the climate of interorganisational cooperation in dyads, higher estimated, and standing out by confidence vis-à-vis the climate of interorganisational cooperation in networks, being relatively lower when estimated with the outstanding role of experience in cooperation [106]. Additionally, M. Maćkowiak and S. Graja-Zwolińska studied the importance of trust in the building of network cooperation in rural tourism [107]. The authors concluded that the building of trust should be a task of primary importance in organisations creating networks and that trust increases an organisation's ability to survive crises.

\section{Materials and Methods}

The research problem that we attempted to solve concerns the subject of the features and attributes that cultural routes have as networks of various heritage entities/organisations, perceived, in particular, from the perspective of values that co-create these networks, especially trust as a building material of mutual relationships, within the cultural route network. Consequently, sustainable management of cultural heritage is based on values within route networks. Based on the results of the research, we also propose an original concept of trust within the network of cooperation within the cultural routes. In response to the presented problem, the following research questions have been formulated:

RQ1. What network features and attributes do cultural routes have and what are the main rules of managing them?

RQ2. What are the values underlying the cooperation network in cultural routes studied?

RQ3. How is trust in the mutual relationships between interorganisational routes manifested and how is it understood in the route organisations?

RQ4. How to research trust in cooperation networks of organisations such as cultural routes?

We decided to adopt a specific strategy to answer the research questions, which consists of an empirical and conceptual part. The first three research questions referred to the empirical studies that 
were carried out on cultural routes, while the fourth research question is of a conceptual character and it refers to proposals for the research on trust between organisations creating cultural routes.

The empirical part was plotted to include case studies. A case study is a research strategy that is focused on understanding the processes that take place within a given case or set $[108,109]$. Case studies may be based on a single case or on multiple cases and concern various levels of analysis [110]. Different types of case studies exist in the literature. One of the most popular typologies is the one put forward by Robert E. Stake, which includes three types of case studies [109]: intrinsic case study, instrumental case study, and, finally, collective case study, which we suggest here and that covers a few cases in order to better understand and explore the phenomena that are of interest to us. Our case studies are based on a qualitative approach with the intention of showing and interpreting the image of the world [111]. Reflective thinking accompanied the research process, which was a continuous process of examining and discussing the impressions, opinions, official documents, and statements of people who are related to routes [112].

We have selected the three largest cultural routes in Poland, which are organised to various degrees: Wooden Architecture Route in Małopolska, Silesian Industrial Monuments Route and the Piast Trail, situated across two provinces-Wielkopolska (Greater Poland) and Kujawsko-Pomorskie (Kuyavian-Pomeranian). The following issues determined this choice:

- while conducting the research on cultural routes in Poland, approximately 600 cultural routes were identified during an extensive search. For each route, a short description was prepared; this description makes it possible to identify the route and to determine the heritage area, the operator, and the level of development;

- we decided that more in-depth case studies would be carried out on the three largest cultural routes, with the highest degree of organisation, having the largest number of route points-sites, with the identity already built around regional heritage and values; and,

- none of the remaining cultural routes is organised in a similar manner or developed to such a degree. Therefore, these three routes are the best example and potential model or direction in route development.

The research was carried out in 2016. In order to collect data, in the study of each cultural route the following four research methods were applied:

- focus group interviews with leaders of the organisations assembled on each route (three group interviews per route, between six and 12 subjects participated in each interview) carried out in the field (in places important for route functioning). The fragments of focus groups interviews used in the article are marked with the letter " $\mathrm{F}$ ",

- in-depth interviews with operators of cultural routes (3 interviews as part of each study), also carried out in the field. The fragments of in-depth interviews used in the article are marked with the letter "W",

- observations on cultural routes (short participant observation), carried out during focus studies and visits to route points, and

- analysis of organisational documents that were obtained during visits to the cultural route (reports and portfolios of organisations, websites of the route and of route organisations).

The order of data collection is illustrated by the chart below (Chart 1).

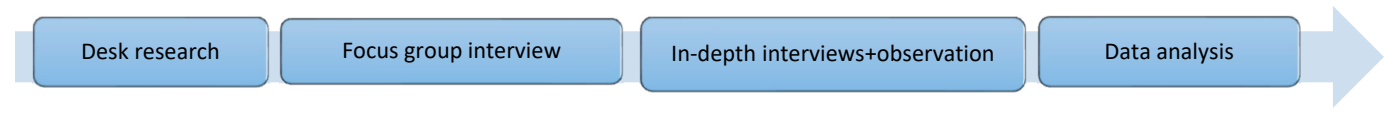

Chart 1. Order of data collection. (Source: own work).

Figure 1 presents the location of the studied cultural routes on the map of Poland. 


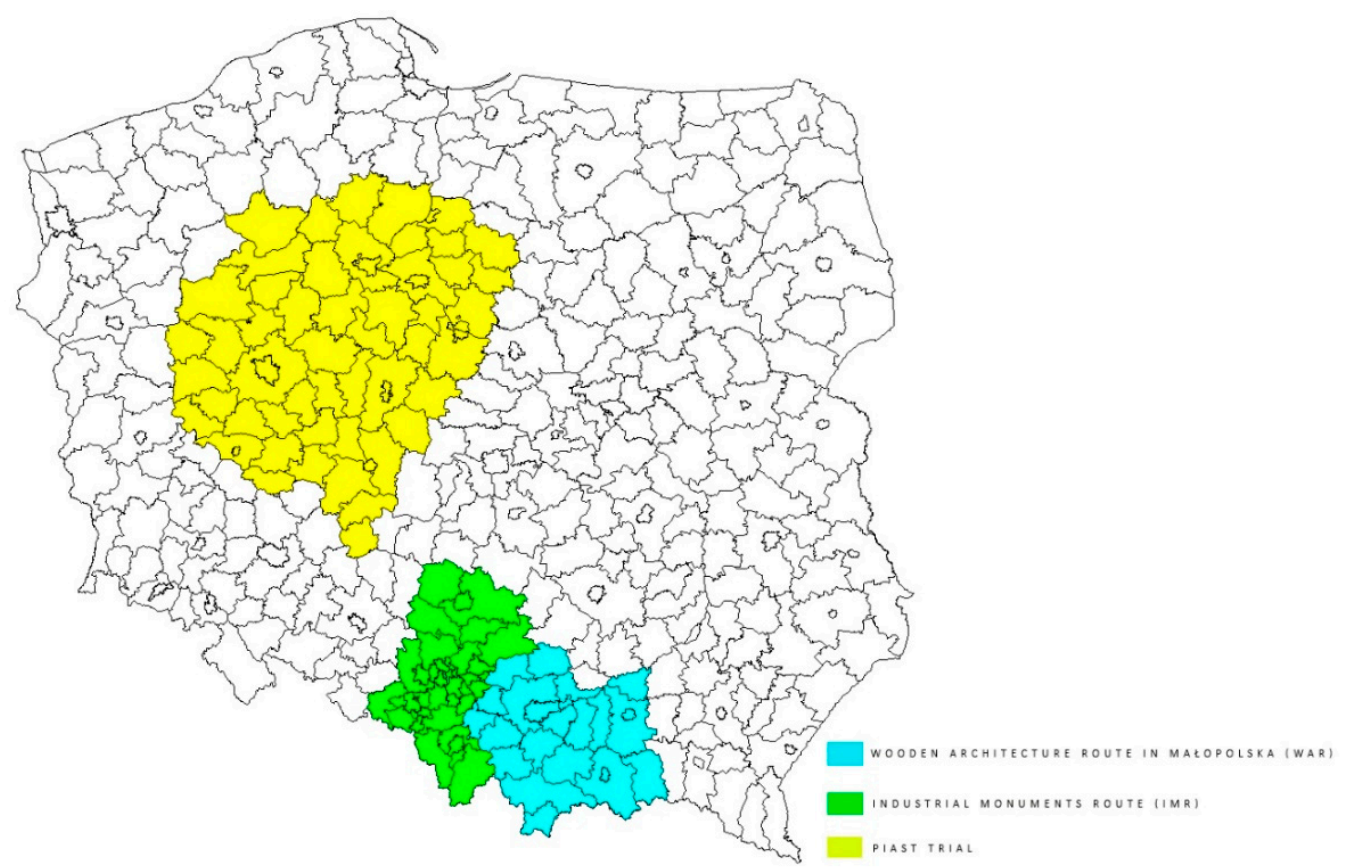

Figure 1. The location of the studied cultural routes on the map of Poland. (Source: own work).

In-depth interviews were carried out on the basis of a partly structured interview questionnaire. Moreover, when a given issue was significant for research participants, they were free to elaborate on it. Each interview lasted for at least an hour. The interviews were recorded, with the consent of research participants, and then transcribed. A scenario was used in the case of focus interviews, and interviews were conducted in accordance with the methodological principles of interviewing. They were also recorded and then transcribed. All of the available route documents, which referred in any way to the research problem, were gathered. Notes of observations that were taken during route visits, while conducting interviews and focus interviews, were also important. After the interviews have been transcribed, and the documents and notes of observations put in order, data analysis commenced. Computer programs were not used for this analysis due to a small number of interviews and documents. All of the researchers read the interviews and documents numerous times in order to identify the emerging dependencies and the holistic image of getting organised within a cultural route.

The conducted research had some limitations. Above all, the research we conducted in selected cultural routes that were focused on the organisation of routes and the values that build them. Trust was just one of them; however, during the research, our respondents referred to its role in building the network multiple times. Hence, on the basis of the conducted research and analysis of the literature, the proposition is to research the concept of trust in cultural routes in the conceptual part of the study and in answer to the fourth research question.

\section{Cultural Routes in Poland-A Case Study}

\subsection{Wooden Architecture Route in Małopolska (WAR)}

Wooden Architecture Route is a network of 255 sites, including churches, Orthodox churches, bell towers, old Polish mansions, wooden villas, and open-air museums, which are among the most valuable heritage sites of the material folk culture. Eight sites from the network were entered in the UNESCO World Heritage List—four wooden churches (2003) and four Orthodox churches. The basis for the functioning of this route is the protection of unique monuments, but also the sustainable socio-economic development of local communities, primarily in rural areas that operate around these monuments. 
The route has been systematically developed in Małopolska since 2001 by Małopolska Province Marshal's Office, which is the official owner of the route, while its management was entrusted to Małopolska Tourist Organisation (MTO)—an association whose aim is to form and implement a policy on the promotion and development of tourism industry in the Małopolska Province. Its members include: "local authorities of the region, local government units, local tourist organisations, industry and social organisations, scientific circles, and entrepreneurs from the tourism sector" [MTO Articles of Association]. Legal entities predominate, but MTO also includes natural persons.

At first, the route was entrusted in a semi-formal way, because the Marshal's Office and MTO had not signed any formal contract. However, for the last couple of years, MTO has been participating in the annual competition for the execution of public tasks and it has been awarded a typical contract to manage WAR by the Marshal's Office of the Małopolska Province. MTO manages the network as a whole while the sites that constitute the network also have their individual owners and managers: private individuals, parishes, public institutions, and non-governmental organisations. The network of sites forming the route covers the entire administrative area of the Małopolska Province-at least one site that was included in the route structure is situated in each municipality.

At the beginning, network affiliation, followed a semi-formal procedure: application for affiliation, an entry in the heritage registry, and, of course, the structure had to be made of wood.

It is noteworthy that, since 2008, a smaller network of route subjects has been operating within the network; it is a liquid network, which is renewed every year. This is the so-called Open Wooden Architecture Route, and its sites are made available to tourists each summer. One year there are 60 sites, the next year 80, depending on the financial resources of MTO (which depend on subsidies of the Małopolska Province under the awarded contract), but UNESCO sites and the sites that accept tourists every year and specialise in providing services to them form the core. The financial aspect is important, because, under the contract, MTO employs site hosts-supervisors who receive tourists and allow them to visit the site.

\subsection{Industrial Monuments Route (IMR)}

The Industrial Monuments Route is a themed tourist car trail that connects 42 of the most relevant and interesting sites representing the industrial heritage of Silesia.

Work on the route started in 2004 and it was opened in 2005. It was an initiative of the province's local government that coordinates and manages the route to this day. Local authorities define the route as " $(\ldots)$ ) a network of industrial culture heritage monuments and a branded tourist product of the Silesia Province". [The Regulations of the Industrial Monuments Route of Silesia Province]. The sites that are officially listed as part of the route are spread across 26 locations in the region. They are immovable properties of industrial culture that are associated with different manufacturing activities in connection with the industrial revolution and the modernisation processes that it entailed. The sites are related to the tradition of mining, metallurgy, power industry, railway, communication, textiles, water production, and the food industry. The Industrial Monuments Route includes existing museums and heritage parks, inhabited worker colonies, and running workshops. The local governments, private individuals, as well as state and private companies, own the objects. The idea of this route originated from the desire to define new directions for the development of the region, of an explicitly post-industrial nature, threatened by degradation due to the regions' increasingly disappearing mining industry and traditions that are connected with it. The creators of the trail wanted to use the region's wealth in a sustainable way, at the same time preserving its cultural uniqueness.

The Industrial Heritage Promotion Office implements the project, which is part of the Department of Culture in the Silesia Province Marshal's Office. The Industrial Heritage Promotion Office employs four people and takes advantage of public funding within an annually drawn budget.

The trail has a precisely formulated mission statement, regulations, functions, and modus operandi. The route is a network tourist product and constitutes "a unique selling point" for the Silesia Province among the regional tourist offers, which has substantially gained in value via synergy according to its 
creators. Following the mission statement, the primary features of the Industrial Monuments Route as a networked tourist product include: authenticity, originality, uniqueness, and attractiveness [The Regulations of the Industrial Monuments Route of Silesia Province, 2015].

The route's network continues to expand. Aside from heritage monuments, there are other entities being anchored-organisations that provide expertise and deal in cultural heritage. The goal is to improve the project's capacity in a number of fields, such as event organisation, or influence on governing bodies and policy makers.

\subsection{The Piast Trail (PT)}

The Piast Trail is a tourist and historical trail that connects the most important sites and monuments that are related to the origins of the Polish State in the 10th century, Christianisation of the region, and the Piast dynasty. Unlike other cultural routes, monuments that are officially listed as part this trail are located across two provinces: Wielkopolska (Greater Poland) and Kujawsko-Pomorskie (Kuyavian-Pomeranian).

At the initiative of Gniezno Starost Office, the work on the route officially started in 2011, much later than WAR and IMR in southern Poland, which allowed the creators to build upon the experiences of the Industrial Monuments Route and the Wooden Architecture Route. However, the first mention of the trail can be traced back to 1966, which is in connection with the millenary of Christianity in Poland. The celebration sparked revived interest in the monuments in the area; several guidebooks extolled the unique qualities of the route and marked its major walking trails [7]. They initially formed a characteristic 8-shape, which can be found on indicative maps to this day.

The existing concept of the route takes into account two main trails. The first one encompasses 15 settlements featuring objects or complexes, 30 stand-alone attractions, and four urban or local routes (Poznań, Gniezno, Strzelno-Inowrocław-Kruszwica complex, and Włocławek). The second trail encompasses eight settlements featuring objects or complexes, 17 stand-alone attractions, and two urban routes (Gniezno and Kalisz).

The trail management framework derives from a specific distribution of powers among the various entities. The first authority in question is the Piast Trail Academic Advisory Board, which was founded in May 2011 by the marshals of Wielkopolska and Kujawsko-Pomorskie provinces. The Board is composed of representatives of science, local government, and industry from both provinces, with the District Head of Gniezno as the body's chairman. The Board is responsible for strategic policies, such as the implementation of the trail's mission statement, the addition and removal of cultural sites, audit oversight, as well as study and research. Another authority-involved in the project since 2016-is the Tourist Cluster "Wielkopolska Piast Trail" (which acts as he coordinator for the Wielkopolska section of the trail). It is a product tourist organisation that was founded by 19 local government units, municipalities, and districts, which makes it a textbook grassroots initiative. Finally, we have the Inowrocław Local Tourism Office, as the coordinator of the Kuyavia section of the trail, assigned this task by the Kuyavian-Pomeranian Province. The Sports and Tourism Departments of Wielkopolska Province Marshal's Office in Poznań and Kuyavia-Pomeranian Marshal's Office in Torun, Wielkopolska Tourism Organisation (the previous coordinator), Kujawsko-Pomorskie Tourism Organisation, as well as array of local government units and cultural sites further support the Piast Trail. Apart from the indicated entities, an extremely important role in the development of the trail is played by local organisations that manage its individual monuments while caring for their sustainable development-directly responding to the needs of the local communities centred on the monuments along the route.

The Piast Trail does not have a codified mission statement or development plans. The central document that establishes the trail and defines the objectives is a letter of intent titled "On the restoration of the Piast Trail", which was drafted in 2012 by the province marshals. Aside from the foregoing document, the local government of the Wielkopolska Province has entered the route into various strategic documents. In particular, the Piast Trail is now considered to be one of the priority tourist 
products of the region, being included in the Tourism Development Strategy for the Wielkopolska Province until 2020. It is worth noting that a similar initiative has not been undertaken in Kuyavia.

It is difficult to assess the structure of the trail, as it is a work in progress (even though, as an idea at least, it is technically the oldest cultural route in Poland), while the still forming networks and affiliations between the sites and other organisations that are connected to the trail are often contradictory. The main organisations within the Piast Trail do not conduct any networking activity-no meetings, training courses, study visits, or other interactions, apart from three academic conferences that were cobbled together by the Advisory Board.

\section{Research Results}

\subsection{The Distinctive Features of Cultural Route Networks and Management Rules in the Network}

In response to the research question No. 1 ("What network features and attributes do cultural routes have and how are they managed?"), referring to the features and attributes of cultural routes as networks, it should be emphasised that the network structures that were adopted by the cultural routes studied are very diverse, ranging from fragmentary and network relationships under construction, through very loose, bottom-up networks (WAR), and ending with formalised and hierarchical permanent network structures, such as on the Industrial Monuments Route. The routes that we examined had various distinguishing features and attributes:

(a) The Industrial Monuments Route is a network structure that is permanent, formalised - functioning on the basis of regulations and admission rules [113] — and very strongly initiated and gradually built by the route coordinator, which is a public organisation [52]. There are specific tools that the coordinator uses to mobilise and activate individual entities due to formally signed agreements between the network entities, but also to enforce certain arrangements and operating standards that result from the signed contract. The route network organisations undertake joint activities, also in a very formal way. The crucial point is the execution of the route development plan, promotional activities, as well as organising joint projects that aim at the development of joint tourist products within the network. What is important, the relationships are collaborative, as the coordinator (route manager) is looking, not only for the full integration of activities, but also many activities in the route network are unified. The emerging hierarchy of entities in the network proves the stiffening of the network structure, which builds permanent structures and lasting mutual relationships. Therefore, certain nodes in the network become more important, as they subject themselves to a formalised audit that enabled the introduction of a gradual categorization of the sites that primarily serves awarding "stars", but also mobilising weaker nodes that do not manage to uphold the route-wide standards. Moreover, receiving the "endangered site" status means the risk of public disgrace for an organisation. At the same time, the route coordinator declares that they would like to build a network of independent entities that make decisions together, while their activities create rather permanent structures-participation in decision-making is practically limited, and there are no validating tools within the network. As a result, the Silesian route is already a largely institutionalised network; it also reflects a certain ordering of the industrial heritage that it explains. Therefore, the network of this particular cultural route is rather informative in nature and the social bonds within it are weak. However, the certain stability of this network should be highlighted-it is a route where the expansion is heading rather towards knowledge acquisition and expert network development. Other entities are being anchored, in particular, those that can contribute their expert knowledge, and are, at the same time, organisations that are devoted to cultural heritage. This is supposed to also serve the expansion of opportunities, especially in organising various undertakings, as well as enhancing its influence on various public decision makers.

(b) The Wooden Architecture Route is a twofold structure, which is managed by a non-governmental organisation. There are two networks: the first one wide and semi-formal (its members were included in the route network based only on their declarations, the necessary condition 
for a site to be incorporated into the route is the status of a wooden architecture that encompasses all entities of the route. The second, much smaller, is of a formal nature (contract), and it covers about $1 / 3$ of the route entities-organisation, where the coordinator performs certain cohesion-enhancing actions, delegates certain tasks, and introduces minimum standards. The annual appointment of the route coordinator by the Voivodeship Marshal's Office also reinforces the semi-formal character of the route, which results in a planning perspective for joint route activities that only span one year. However, overall, most of the route activities are done outside the management organisation, thanks to the activity of the route operators themselves, often very closely connected with the wooden architecture site. The mutual exchange of information, mutual non-formal contacts, recommending and helping in activities around the route heritage are factors within the network that are even more significant than the coordinator's activities. The network of informal relations between guides working on route sites should also be highlighted. Their cooperation is often based on the friendship between people connected to the route and their willingness to offer assistance. It is manifested, among others, through mutual recommendations of nearby sites and services of guides who work there, or opportunities to join projects that are organised in the region, which also stems from the belief in mutual benefits that such cooperation might yield. As a result, this route's network has a stronger social than formal dimension. The social and cultural capital of the Małopolska (Lesser Poland) Province is important in building the route, the methods, and instruments of network or route management from the coordinator's side, should be less favourably assessed. The strong non-hierarchy of the route, the developmental scope of action [113], and the cooperative relationships between the entities should be emphasised. Moreover, exclusion from the network, or any form of "disciplinary" action rarely occurs. There are no established standards of functioning within the network, apart from the initial conditions. Fragmentation of a large network (over 250 entities) reflects the existing economic and social structure, which is historically shaped in the province (small economic entities and agricultural entities operating within various interconnected networks).

(c) The Piast Route is a fragmentary network, which is still under construction (even though it is the oldest of the studied routes), with a few management centres (mainly from the non-governmental sector) - at least five entities coordinating cooperation within the route, including the three strongest ones, can be identified. This network can be labelled a technocratic network, since the Programme and Scientific Council has the strongest influence on its shape. The coordination situation is made more difficult by the fact that only the Programme and Scientific Council is an organisation with a reach above the provincial level. Other entities only operate in their own provinces, usually only voluntarily contacting others for joint actions. Initially, the idea and concept of the route, created before the formal restitution of the route, which was not implemented due to the lack of a single network coordinator, was strong and well crystallised. The current networks of the links between the entities of the route are rather built on grass-roots, neighbourly relations, community of values, and the importance of common heritage, which were also formed much earlier, before the formal establishment of the route. Relationships within the network are diverse, being sometimes community-based on relying on social relations, and also competitive-networks and links between sites or organisations on the route often have completely opposite directions. The route's geographical extent and the inclusion of two administrative units exacerbate the fragmentation or incoherence of the links within the network. Particular management centre entities undertake their own activities for the selected nodes of the route and initiate specific projects without a shared vision or a network development strategy. Particular route entities protest the homogeneity through the Programme and Scientific Council, and there is no consensus in terms of the responsibility of particular entities or the scope of coordination. During the research, certain respondents underlined that it is precisely this diversity of perspectives, ideas, and concepts, and not striving for unity, which determines the beauty of this route.

All routes studied, which are understood as network structures, are also differently managed. In general, usually one organisation manages (or only coordinates the activities). In the case of the Wielkopolska (Greater Poland) route, attempts are also made to introduce such a solution that is 
difficult, because the route is located in two provinces and formal and legal reasons make it difficult to establish a single public sector coordinator. Therefore, it can be concluded that route networks are managed through a leading organisation [114,115]. The organisations-route points in the provinces of Silesia and Małopolska expect that the lead organisation will take management actions and they usually are able to submit to the procedures and management methods that they apply, seeing their benefits. Meanwhile, the formation of the Piast route network is partially forced. The informal network of the trail was built on the idea, and subsequent management and ordering activities gradually triggered resistance, competition, and the emergence of different organisations to coordinate the route activities.

Formal, strong, and often also hierarchical networks are created, where the public sector is the route coordinator. Perhaps the explanation is the organisational isomorphism or functional linking [116], especially the mimetic isomorphism, because, in the light of G. C. Homans' theory, cooperating individuals tend to become similar to each other in order to achieve greater benefits within the relationship. Non-governmental organisations that coordinate the activities of the routes in Lesser Poland, and Greater Poland are less formally building the formal networks, leaving networking to the route organisations, grassroots leaders, or even local communities.

\subsection{The Values around Which Routes Are Built}

In responding to the second of the research questions posed ("What are the values underlying the cooperation network in cultural routes studied?"), it is necessary to pay attention to the motivations that underlie the decision of the creators of cultural routes to create them. For the route creators, the basic point of reference in the sustainable heritage management process from the very beginning has been people who build a specific narrative that is based on the things retained from the past, memories, and stories that form the surrounding ecosystems [26,27]. Hence, the key value appearing in the context of all routes has been man, both seen from a historical perspective, as the creator of the heritage, as well as a contemporary individual trying to develop it creatively and in a sustainable way. In this sense, one should also note the symbolic dimension and the value given to the routes by residents and local route communities that can be treated as an indicator of emotional ties that exist between residents and a given site, organisation, or landscape dominant. Local people remember many of the route's sites, e.g., as working establishments. After closing and converting, they became leisure spaces that often require additional efforts to convince former employees and their families that the change was sensible, and to acquire them as customers and sometimes even "ambassadors" of these sites. Cultural routes, which are also one of the forms of protecting heritage sites, often serve to preserve those elements of the past that allow for local communities to take root in the present and referring to the words of Lowenthal [117] (p. 5), as referred to in the introduction, are used to build the "here and now" of the region's inhabitants, inspiring them to undertake new business activities.

In all of the studied cases, the intentions of the route creators focused on: (1) the will to boost the sustainable region's economic development in the area of tourism, especially rural and post-industrial areas, (2) strengthening cultural heritage awareness among residents and tourists visiting the region, and (3) activating local communities. Hence, both utilitarian values that are related to the economic development of the route region and economic activation of its inhabitants, as well as the values related to local identity appeared in parallel among the routes studied. Hence, there is often a sense of synergy between the various values that reveal the cultural route built around the heritage: "Recognizing the Route as "material wealth of both provinces" they define goals of synergy and achieve mutual benefits resulting from the popularisation and development of the Route" [Szlak Piastowski 2012]. It was clearly emphasised during the research that the route functions as a reconstruction and creation of identity, not only local, but also national. It is an important element of history, but also a way to build social cohesion-the route and its values, and the contents that it brings, connect generations, as well as people with different material status. Importantly, the local awareness of heritage, pride, and a sense of connection with the place and heritage are also on the rise. 
Although each route had a manager (or managers), each access to the network of individual sites and their managing entities has had a voluntary character; hence, it can be stated that the routes are built primarily on local cultural and social capital, which gives them of unique character. The result of such an assumption is the conviction of the respondents that in case of the routes "there is no possibility of tough management. Here you have to work out the values together" [F5]. This is why it is important to mutually negotiate and agree on what is present in the relationships of the route entities. The values that are the driving force of the routes regulate the mutual relations between people and organisations that create the route and route managers, and influence the dynamics of network development within cultural routes.

Observing the way of organising the routes studied, it seems that the key to the sustainable development of their idea of routes was the commitment, willingness to cooperate and develop understood in the perspective of individual sites, as well as the trail as a whole. The participants of our research drew attention to the question of emancipation, which accompanied the processes of creating the routes. Its level was different in the case of the routes that were studied-in highly formalised networks (ZST) and lower and more informal ones (SAD), respectively, higher. One of the respondents that works at SAD emphasises: "What I am happy about is that it is bottom-up, no attempt was made to force anything by any organisation. It is not easy to build guest houses" [F2].

On the Piast Route, it was emphasised during the research that "We have such a situation, we all work together, we like each other, we act together. It is important to try to make more" [F1]. For this reason, it is worth emphasising how significant informal relations between the guides working at the sites situated on the route are for route organisation; in fact, route organisation develops on the basis of such relations. This proves that a route is a community of persons whose cooperation is usually based on friendship between "route attendants" and on the willingness to help one another. It is visible in e.g., recommending to one another the sites nearby and the services of guides working there or the opportunities to get involved together in projects that are organised in the region, which also stems from the conviction that both parties may benefit from such cooperation, which, among others, is strongly developed outside of the organisational structures on WAR and TPT.

Regional sustainable development that is based on the idea of cultural routes is understood by its stakeholders in various dimensions: in social, economic, and cultural terms, as manifested in activities that aimed at sustainable tourism development and activating residents (e.g., by including them in the activities on the route: "There are no eggs, so we go to a neighbour who will also earn" [F1]) and develop their cultural competences by expanding the cultural offer available to them, as evidenced by the cycle "Muzyka Zaklęta w Drewnie" ("Music Enchanted in Wood"), regularly organised at the SAD or the Industriada festival, which is the flagship project that was carried out every year at the PCT. The Stakeholders of the route, satisfying their diverse needs through the use of cultural heritage resources along the route, have a significant impact on their preservation and development, and at the same time these resources significantly affect the stakeholders themselves, their development, and relations with the environment. In this way, the interaction between the resources of cultural heritage and its participants within the routes takes the form of a dialogue based on values such as human rights, cultural democracy and diversity and mutual understanding, and cross-boundary exchanges, the role of which in building the routes, and the European Institute of Cultural Routes emphasises the communities creating them [10].

Finally, the last value that occurred in the opinions of the studied representatives of trails was dignity. The respondents did not directly mention it, but it occurred in the words of the representatives of both the Wooden Architecture Trail and the Technology Monuments Trail. What is meant here is dignity understood as a value that the local community has, in a way, been deprived of, either through the deprivation of cultural heritage, as with industrial facilities, or through forgetting or peripherisation of the heritage of wooden architecture in small villages. These places and buildings, before the trail was created and started, were often forgotten and doomed for demolition or gradual degradation. Building a trail network gave them the new value, but it also brought dignity back to its users and inhabitants. 
Accordingly, it happens with mines and industrial facilities within the Technology Monuments Trail, where former employees, strongly connected to them, discover their places, show their relatives their workplaces: "Only several years ago these industrial facilities were only a tie, not prepared to anything, and no one knew what to do with them [ ... ] now inhabitants come to us-their self-esteem once so low grows, people did not recognize that Silesia is so valuable. They now bring their guests; friends and their feeling of pride increases" [W-1]. They regain their dignity thanks to the trails, and their past becomes important not only for them, but the local community and tourists.

\subsection{The Manifestations of Trust in Relationships on Cultural Routes}

Answering the third of the research questions posed ("How is trust in the mutual relationships between interorganisational routes manifested and how is it understood in the route organisations?"), there are several expressions of trust in the relationships between individuals and organisations that create the studied cultural routes.

First of all, it should be emphasised that the community is an extremely important value for the "route-goers". Relations between the "route-goers" are based, on the one hand, on the sense of the region's heritage community, but, on the other hand, they also clearly have a interpersonal character, where individual leaders cooperate, not only in formal relationships. In turn, relationships between route managers and the individual entities creating them are diverse-the strongest are within a smaller network, i.e., those that are based on a formal contract and making the site available to tourists. In a wider network, there is no hierarchization of entities, exclusion outside the network, as well as any "disciplining", are quite rare. A who works on the SAD emphasises that the "Route certainly integrates people, I can talk to people who are on the route, people get to know each other" [F4]. The degree of tightening community relations between people and organisations on the routes studied is different-being clearly higher on the SAD and the Piast Route, where the degree of formalization of relations between the manager and objects on the route is smaller, and interpersonal relationships are based on friendship and the willingness to help each other. The conviction regarding the strength of the community on the routes is the basis for their development. Exchange of ideas, conviction about a common role in the preservation, and development of local heritage are the driving force for people who co-create routes are associated with this possibility of joint action. "I observe a certain integration in myself, people start to see some sense in that there is a point on the route, that it makes sense" [F5].

People who co-create the routes are convinced of the strength of joint action, which is manifested in sharing ideas for activating and developing routes. Guides working on the SAD emphasise that “(...) there have been many competitions now, so we are networking. I can't, Agata can't, but a friendly foundation can" [F5]. People that are connected with the SZT think similarly about the routes “... We have advertising brochures, we advertise, we do something together-not only Industriada. Also, between individual sites, such a bottom-up operation" [F3]. They do not perceive each other as competitors fighting against each other, e.g., for tourists or for financial means for further activity, and instead perceive opportunities that result from cooperation. The manifestations of cooperation can be found, among others, in a willingness to recommend sites on the route, which is a common practice among "route-goers".

The sense of community, gradually strengthening the relationship and cooperation between entities belonging to a network of trails is a manifestation of trust as—according to B. Misztal [118] — trust creates the sense of community. Trust is the basis for building not only relationships within a network of trail entities, but also for creating sub-networks within local communities:

"Building a very strong network of cooperation, yet not based on such pyramidal or hierarchical management, but a junctional network, that is, many junctions within a network, which in turn have their subnetworks built, and they are very strongly anchored to local communities, that is, these facilities should have, should be important centres of the local life and for these communities they are to be perceived as attractive places for leisure time". $[\mathrm{w}-1]$ 
Building the culture of trust [119] can also be observed within trails, which are based on a clearly identified structural source of this culture, that is, cultural heritage.

In the relationships between cooperation networks, justice also comes as a value that is particularly expected from coordinators of such a trail, but also between entities in the network. First of all, behaviours of coordinators are to a large extent negotiated based on the value of justice, particularly with reference to the principles of joining a trail network, creating common working standards for a given trail, the employment of people cooperating at this trail, or the organization of joint projects. To strengthen justice in the mutual relationships, coordinators search for support, particularly from expert organizations that may validate their decisions:

"Cooperation with them [experts] is very important for us to the extent in which we have an external expert on cultural heritage and this dispenses us a little from the burden of whether we have any affection or dislike towards a given facility". [W-5]

However, it is essential to negotiate "just" behaviours as for "expert" justice, as imposed by members of a trail network, the feeling of injustice, and the lack of understanding for the needs of some entities in the network occurs. Such was the situation with the Piast Trail, where, after an audit carried out, the Scientific Council of experts deleted some organizations from the trail: "The trail was narrowed down, some facilities were deleted, of course the major ones remained but some from the area are missing because they did not match the new idea" [W-4]. With some representatives of the trail entities this evoked the feeling of a lack of understanding and of injustice: "When managing a cultural trail, one needs to consider the variety of perspectives and stakeholders, which means no changes should be made without looking at the needs" [W-2]. As a consequence, some saw the deficit of integration and, to some extent, loosening of the community: "We would like to have more integration at the basic level, integration, so that both centres, the whole trail, act together based on synergy, with mutual benefits" [W-1].

Secondly, relationships between certain entities in the network also refer to justice. It is clearly visible with the Wooden Architecture Trail, where mutual cooperation and responsibility not only for one's own facility, but also the whole trail network are emphasised. Hence, the feeling of justice is linked to the necessity to increase professionalism and learning from each other.

The third value that also manifests a certain level of trust in a trail network is involvement. Coordinators took various actions to increase involvement of network participants in each of the trails studied, whereas their effectiveness is visible if the trail entities clearly see the benefits of being involved in a trail:

"The involvement came upon realization that there are benefits of being on a trail. These are marketing issues, a "trail day"-this is what boosts imagination most. Joint promotion is also a benefit". [W-6]

At the beginning, when forming a trail (for the Piast Trail this phase is still ongoing in some fragments of the network), working on increasing the involvement of all entities is in the hands of the coordinators. However, more and more entities in a network see the real benefits of being involved, and the coordinators support any activity and joint projects within a trail:

"The coordinator forces some facilities to take activities. For example, my gallery works from one exhibition to another. We are encouraged to constantly do something. What works here is imitation, the motivation that others act as well. We act, cooperate with neighbouring facilities within a trail". [W-1]

As some representatives of trails say, involvement is the essence of the existence in a trail network, and it should be the basis for building mutual relationships, but also excluding uninvolved entities from the network.

In summary, the studied routes have both material (mostly historical monuments, but also interesting sites and spaces) as well as intangible resources (e.g., knowledge regarding the management 
staff, social norms, values). Therefore, not only do they inform, but also generate culture. Based on the conducted research, it is possible to state that cultural routes include constituting relationships that determine the scope of responsibilities and rights of particular members, associative relationships that are created as a result of peoples' and communities' decisions, and personal relationships that are formed in the process of interactions. It can be assumed that associative relationships were initially dominant, and entities were expressing their readiness to cooperate; therefore, trust also existed. The cooperation become formalised, a constituting relationship was formed that served as insurance for this trust. In the course of cooperation, a personal bond also developed. Entities gain a sense of relative security due to this relationship. These values can support maintaining and developing trust.

In the studied routes, the process of self-organisation plays a significant part. This process assumes the presence of trust between given entities that are able to overcome obstacles to the joint activity when their contacts are well developed and they share a history of cooperation. Self-organisation is the process of shared understanding that requires collective interaction and communication, which results in the creation of a structure that is based on objectives shared by all members of a given system [120] (p. 105).

However, local government agencies or employees of public administration offices manage the featured routes. For that reason, the self-organisation process itself is secure; we can even venture a statement that it is supervised and shaped from the outside. It is executed through the already known mechanisms: creating strategic frameworks, developing self-organisation monitoring procedures, through joint result assessment, offering support and assistance, by providing appropriate information, legal counsel, meeting places and financial support, or by designing institutional environment where self-organisation occurs. José Nederhand and Victor Bekkers described these mechanisms in detail [120].

\section{The Concept of Studying the Role of Trust in Cultural Routes' Development}

The starting point for answering the fourth of the research questions posed (How to research trust in cooperation networks of organisations such as cultural routes?) was the conviction that there are many methods, techniques, and tools for studying trust, as well as that the research approach that is presented here did not give satisfying results. Various questionnaires are used (some of them were developed for the study of trust between employees, between organisations, and a part of them to study trust in relations with clients). A significant part of the researchers uses experiments. The methods, techniques, and tools used so far can be a rich source of new research concepts. However, our proposals, aim at creating research assumptions that can be used to study trust in networks that are composed of various entities creating cultural routes. Four assumptions constituted the basis for the formulation of the proposal.

\subsection{Assumption 1-network types, trust and values}

The routes that we present are examples of social and calculative networks. Trust plays an important role in both types of networks, but the calculative network is regulated by meeting the economic expectations of their members [121]. Taking into account the network characteristics made, and, in particular, the types of entities comprising the network-their values, formalization degree, as well as motives of action, goals, and interests, it can be assumed that trust plays an important role in their functioning:

- anticipatory, resulting from the conviction that "beneficial actions of other people will be also in relation to us once we have established relations with them" [61] (p. 100),

- rational-collective-resulting from rational decisions and the collective nature of the network [122],

- based on knowledge-resulting from the possibility of predicting behaviour based on the history of interactions (the better we know someone, the better we anticipate their behaviour and predictability increases trust) [123], and 
- a system of values (ethical, autotelic, and other) agreed and accepted by network members influences the perceived trust. Therefore, in this case, we can talk about trust that is based on values. The conducted research shows that, among the entities (people and organisations) that co-create cultural routes, a sense of identity, belonging, and "common roots" prevail.

Our assumption is that, in the studied networks, we are dealing with a relational nature of identity. This feeling is agreed on and maintained in the processes of interaction [124]. An important role in maintaining the sense of identity is played by the network leaders, who must work for cooperation, participation, and promotion of a common sense of identity among the network's members [125], the information exchange process [126], and what the respondents pointed out in our research: "We have this situation, we all work together, we like each other, we act together. It is important to try to make more" [F2]. Researchers point out that a sense of belonging is a "behavioural" guarantee that the network will work well [127].

Thus, the operation of the network is dependent on the interaction between them, which, in turn, is dependent, among other things, on the sense of belonging to the network. Moreover, the sense of belonging plays an important role in the information sharing process [128].

Common roots, a system of values, and a sense of belonging are the main determinants of the community-as a specific human group [129-131]. Common roots are the motive for creating networks, but, above all, this concept is related to the awareness of network members (that something links them, encourages them, mobilises them to cooperate).

\subsection{Assumption 2-connections with justice}

Justice is widely recognised as a superior value and it can therefore be considered as a basis of trust. The relationship between trust and different types of justice were demonstrated in various earlier studies in various disciplines [132-134].

Distributive justice dominates the studied networks-according to which each participant of the network should be treated as equal to others [135], and interactive justice (in which a sense of justice is felt in relationships with other entities forming the network).

\subsection{Assumption 3-connections with commitment}

The full commitment of network participants plays an important role in creating and maintaining trust. The relationship between trust and commitment has already been studied [136-138].

W. Czakon [139] drew attention to the problem of commitment in networks. Trust and commitment are essential for any process of exchanging, maintaining, and developing mutual relationships [140].

A specific role should be attributed to value-based commitment given the nature of the networks that are described and the types of trust identified-resulting from the impact of identified and accepted organisational values. This commitment may be stronger than economic engagement-based on material and calculative exchange. The level of which is dependent on the comparison of costs and profits. Simplified relations between particular values are shown in Figure 2-Relations between trust and other values.

\subsection{Assumption 4-research approach}

We recognise that three basic research approaches are possible.

The first, process-based approach assumes that common roots and a sense of identity and belonging create a network. There is an initial anticipatory trust that is influenced by specific types of commitment and justice. Economic commitment is less important than value-based commitment. The level of trust depends on interactional and distributive justice, whether the subject of distribution is information, promotion, image, and possible economic benefits. The sense of belonging and identity is also the result. Their quality depends on how trust develops during cooperation. The sense of identity is transformed (as pointed out by E. Goffman). It may turn out that the egoistic attitudes of individual 
entities will lead to network fragmentation and it will weaken trust. Trust itself is both the input resource and the product of this process.

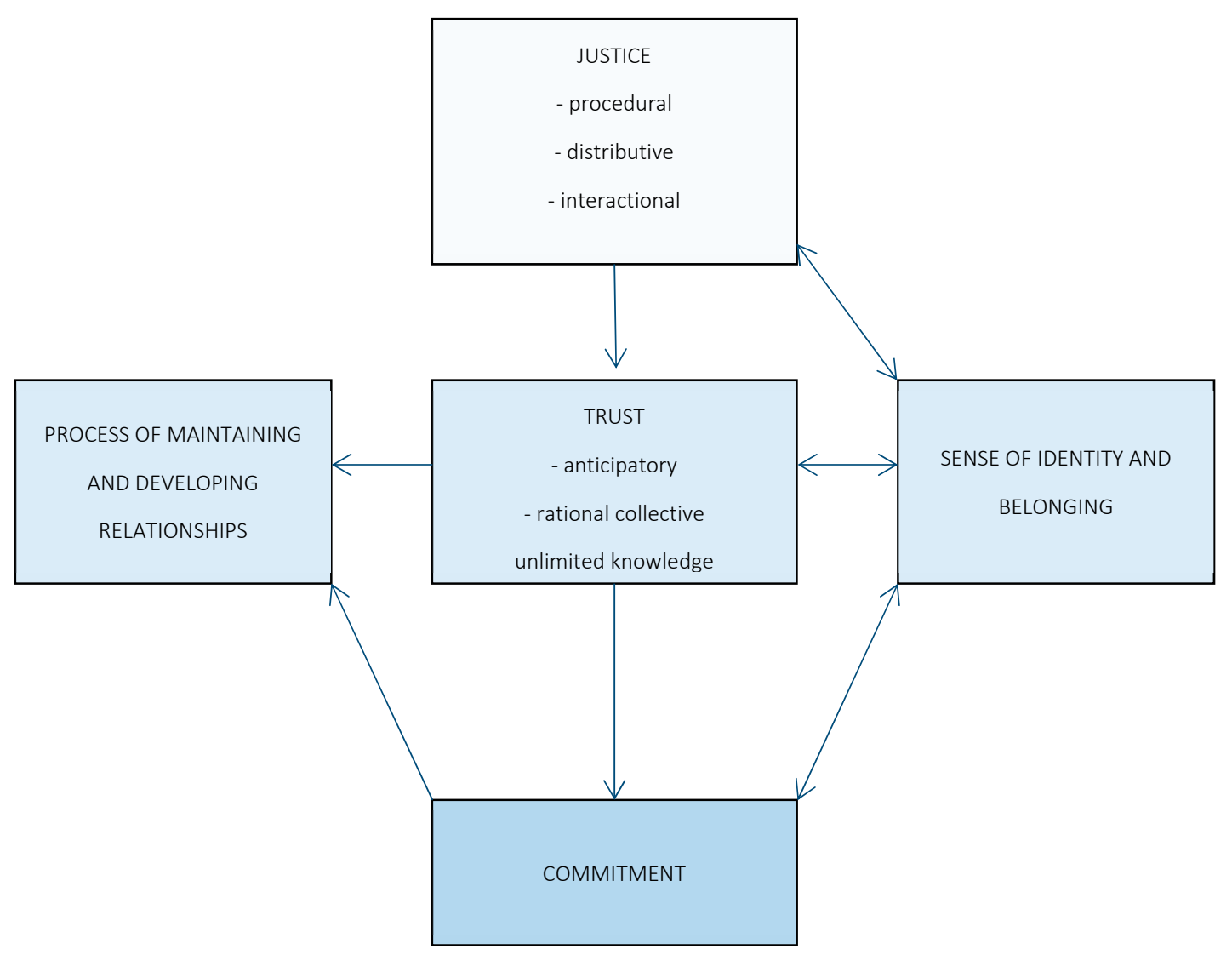

Figure 2. Relations between trust and other values. (Source: own work.)

The second, system-based approach assumes that there are relationships between particular types of values. For example, a strong relationship exists between a sense of belonging and commitment. Interactive justice has strong links with the sense of belonging to the network, since it shapes the information exchange process and, because it plays an important role in the information sharing process, it affects trust-based knowledge. Similar relationships exist between all values described.

The third approach, when is based on relational agreements, consists in studying objectives pursued by individual entities. These goals may be both intangible and tangible, but they do not necessarily have to be integrated and known to network participants. Their method of implementation undoubtedly influences commitment and trust and, consequently, the sense of interactional and distributive justice.

\section{Final Conclusions}

In conclusion, we should look at cultural routes from two perspectives. Firstly, they are constructed, shaped, and managed by, and in response to, the demands of the present, in which contemporary communities living in areas with rich cultural heritage have come to function. Thus, "a heritage route is composed of tangible elements of which the cultural significance comes from exchanges and a multidimensional dialogue across countries or regions, and that illustrate the interaction of movement, along the route, in space and time". [12].

Secondly, as evidenced by our case studies, they are also one of the basic tools of cultural policy at the regional level, while, at the local level, they constitute an element of local policy, which is based on sustainable social and economic development, with the latter, in particular, being based on cultural tourism. Each of the studied cultural routes acts as a kind of network of monuments around which the 
life of local communities is concentrated-its cultural life, since the monuments on the route constitute anchor places that allow for the inhabitants to discover and better understand their roots, and then draw from them in a sustainable way: acting as an inspiration for the development of social, cultural, and artistic activities, as well as business activity-as an incentive for the development of economic activity. It is worth pointing out that this interaction with heritage always creates a feedback loop-on the one hand, heritage inspires, and on the other hand-people who are the 'heritage owners', as a result of this inspiration, strive for their heritage to last and develop in a sustainable way, responding to the needs of the environment.

It should be noted that all three studied routes are built in areas where tourist activity has not been very encouraged before, although there are node points within each route that draw significant numbers of tourists (particularly route points in Krakow, and to a smaller extent in Poznań). From the perspective of regional public policies in the area of culture and tourism, creating cultural routes in the broader sense prevents the tragedy of a common pasture [141], thanks to the attempt of dispersing tourist streams towards different points on the route (which is clear in the example of the Lesser Poland route), and it prevents the excessive exploitation of cultural goods. Therefore, the value and significance of routes in this context is relatively unnoticed, and it also explains the push towards top-down building of certain route networks to cooperate for the common good-reducing the exploitation of the most popular areas of cultural heritage and enhancing areas where heritage is relatively unexplored.

Cultural routes in our understanding have the character of organisational networks of various natures, which range from fragmentary and network relationships, to very loose, bottom-up networks to formal and hierarchical permanent network structures. Network structures that create routes have different, often contradictory features, depending on the assumptions that are adopted by the creators or the coordinator of the assumptions of its functioning: a different level of formalization of activities, bottom-up or top-down, with a public or non-governmental coordinating entity, with hierarchical or opposite-non-hierarchical relationships between the coordinator and other network entities, with diverse activities and the involvement of entities within the route, as well as cooperative or collaborative relations between them.

The most important values that bind entities within the route networks were associated with people living in the route areas, as well as around the utilitarian values that are related to sustainable economic development of the route region and economic and social activation of its inhabitants, as well as values that are related to local identity. The route networks built around the value of cultural heritage were open to constant revision and change, as a source and result of social interactions, both within a specific group and between groups, artefacts that are chosen by them, and values that are assigned to them. These processes are illustrated by the example of the studied routes where the observation of their development allows for noticing different directions of network formation, as well as parallel ideas for routes that are shaped by people creating and managing them.

In light of the conducted research, trust was not a value that appeared directly in the statements of the interviewed route representatives, although, in light of current research, it is one of the key values that form the basis of the relationships within the networks. We have only identified certain manifestations of trust existing between entities or other related values linking the entities within the route.

Our research proposal, which takes into account the results of the research, has proven that trust in the network is strongly associated with various other values. While the relationship between trust and commitment or justice is well known, it is worth carrying out further research regarding the sense of belonging and identity. These are values that can be of great importance in the process of building and sustaining various cultural undertakings.

The study of trust in networks should take into account different types of networks and various types of trust, as well as the stage of life of these networks (whether they are at the stage of shaping, working out standards, effective cooperation, or at the final stage of their existence). A broad range of factors can influence the level of trust in the network, for example-informal information exchange 
processes [142] and goals pursued by network participants [143,144]. Not all types of values support the development of trust. For instance, advance commitment can destroy the initial trust. To conclude, it would be advisable to also refer to critical reflections concerning trust as the "main actor" within cultural routes networks. This can be reduced to three main assumptions. Firstly, trust in the studied routes does not cover the entire network to an equal degree-it is stronger or weaker in particular areas, which stems from various reasons (e.g., frequency of interactions, interests, etc.) Therefore, with time, the inability to level these differences can contribute to the fragmentation of the network. Secondly, trust can connect various groups exhibiting unethical—or more broadly, counterproductive-behaviours. Such a situation can occur where various support groups, or interest groups (e.g., management-level employee and site owners), are forming. Thirdly, certain entities can attempt to build as many trust-based relations as possible, which may weaken the social network (one of the so-called 'trust traps').

Author Contributions: Conceptualization: E.B.-W., A.G., M.B.; methodology: E.B.-W.; investigation: E.B.-W., A.G.; resources: E.B.-W., A.G.; data curation: E.B.-W., A.G.; writing-original draft preparation: E.B.-W., A.G., M.B.; writing-review and editing: E.B.-W., A.G.

Funding: This research received no external funding.

Conflicts of Interest: The authors declare no conflict of interest.

\section{References}

1. Hawkes, J. The Fourth Pillar of Sustainability: Culture's Essential Role in Public Planning, Cultural Development Network (Vic.); Common Ground: Melbourne, Australia, 2001.

2. James, P. Assessing Cultural Sustainability: Agenda 21 for Culture; UCLG: Barcelona, Spain, 2014.

3. James, P.; Magee, L.; Scerri, A.; Steger, M. Urban Sustainability in Theory and Practice: Circles of Sustainability; Routledge: London, UK, 2015.

4. Soini, K.; Birkeland, I. Exploring the scientific discourse on cultural sustainability. Geoforum 2014, 51, 213-223. [CrossRef]

5. Barthel-Bouchier, D. Cultural Heritage and the Challenge of Sustainability; Routledge: New York, NY, USA, 2016.

6. Hall, S. Representation: Cultural Representations and Signifying Practices; Sage/Open University: London, UK, 1997.

7. Kirshenblatt-Gimblett, B. Intangible Heritage as Metacultural Production. Mus. Int. 2004, 1-2, 52-65. [CrossRef]

8. Ashworth, G.; Graham, B.; Tunbridge, J. Pluralising Pasts: Heritage, Identity and Place in Multicultural Societies; Pluto Press: London, UK, 2007.

9. Pekham, R. Rethinking Heritage: Cultures and Politics in Europe; I.B. Tauris \& Co Ltd.: New York, NY, USA, 2003.

10. The ICOMOS Charter on Cultural Routes. International Scientific Comittee On Cultural Routes (CIIC) of ICOMOS. 2008. Available online: http://www.icomos-ciic.org/CIIC/Charter_Cultural_Routes.pdf (accessed on 20 December 2018).

11. Dessein, J.; Battaglini, E.; Horlings, L. (Eds.) Cultural Sustainability and Regional Development: Theories and Practices of Territorialisation; Routledge: London, UK, 2015.

12. World Heritage Committee. Routes as Part of Our Cultural Heritage. Report on the Meeting of Experts, Madrid, 24-25 November 1994. Available online: https://whc.unesco.org/archive/routes94.htm (accessed on 20 December 2018).

13. Global Report on Cultural Routes and Itineraries, Affiliate Members Report: Volume Twelve; World Tourism Organization: Madrid, Spain, 2015.

14. Murray, M.; Graham, B. Exploring the dialectics of route-based tourism: The Camino de Santiago. Tour. Manag. 1997, 18, 513-524. [CrossRef]

15. Naser, N. Planning for Urban Heritage Places: Reconciling Conservation, Tourism, and Sustainable Development. J. Plan. Lit. 2003, 17, 468-479. [CrossRef]

16. Ashworth, G. Planowanie Dziedzictwa; Międzynarodowe Centrum Kultury: Kraków, Poland, 2015.

17. Smith, L. Uses of Heritage; Routledge: London, UK, 2006. 
18. Tourism and Heritage 2018. Available online: https://ec.europa.eu/culture/sites/culture/files/5-tourism-andheritage-10-european-initiatives-factsheet.pdf (accessed on 20 December 2018).

19. Campolo, D.; Bombino, G.; Meduri, T. Cultural Landscape and Cultural Routes: Infrastructure Role and Indigenous Knowledge for a Sustainable Development of Inland Areas. Procedia Soc. Behav. Sci. 2016, 223, 576-582. [CrossRef]

20. Pirson, M.; Dierksmeier, C.; Goodpaster, K. Human dignity and Business. Bus. Ethics Q. 2014, 24, 307-309. [CrossRef]

21. Klarić, V.; Androić, M.; Nevidal, R.; Horjan, G. (Eds.) Managing Visitors on Thematic Cultural Routes Handbook; Ministry of Tourism of the Republic of Croatia-Lujzijana Association: Zagreb, Croatia, 2013.

22. World Tourism Organization. Affiliate Members Global Reports, Volume Twelve-Cultural Routes and Itineraries; World Tourism Organization: Madrid, Spain, 2015.

23. Siguencia, L.O.; Gomez-Ullate, M.; Kamara, A. (Eds.) Cultural Management and Tourism in European Cultural Routes: From Theory to Practice; Publishing House of the Research and Innovation in Education Institute: Czestochowa, Poland, 2016.

24. Häfele, E. European Cultural Routes; Federal Ministry of Economy, Family and Youth, Department for Tourism and Historic Objects: Vienna, Austria, 2013.

25. Bogacz-Wojtanowska, E.; Góral, A. Networks or structures? Organizing cultural routes around heritage values. Humanist. Manag. J. 2018, 3, 253-277. [CrossRef]

26. Holden, J. The Ecology of Culture. Available online: http://www.ahrc.ac.uk/News-and-Events/News/ Documents/AHRC\%20Ecology\%20of\%20Culture\%20\%28A\%29.pdf (accessed on 15 December 2018).

27. Góral, A. Ekologia dziedzictwa. Zarzadzanie Publiczne 2017, 2, 119-130.

28. Buttimer, A. (Ed.) Sustainable Landscapes and Lifeways: Issues of Scale and Appropriateness; Cork University Press: Cork, Ireland, 2001.

29. Relph, E. Senses of place and emerging social and environmental challenges. In Sense of Place, Health and Quality of Life; Eyles, J., Williams, A., Eds.; Ashgate: Aldershot, UK, 2008; pp. 31-44.

30. Tuan, Y.F. Space and Place: The Perspective of Experience; Edward Arnold Ltd.: London, UK, 1977.

31. Vecco, M. A definition of cultural heritage: From the tangible to the intangible. J. Cult. Herit. 2010, 11, 321-324. [CrossRef]

32. Lenzerini, F. Cultural Identity, Human Rights, and Repatriation of Cultural Heritage of Indigenous Peoples. Brown J. World Aff. 2016, 23, 127-141.

33. Shao, Y.; Eckart Lange, E.; Thwaites, K.; Liu, B. Defining local identity. Landsc. Archit. Front. 2017, 5, $24-41$.

34. Conway, M.A. The inventory of experience: Memory and identity. In Collective Memory of Political Events; Pennebaker, J.W., Paez, D., Rime, B., Eds.; Lawrence Erlbaum Associates: New York, NY, USA, 1997; pp. 21-46.

35. Devine-Wright, P.; Lyons, E. Remembering pasts and representing places: The construction of national identities in Ireland. J. Environ. Psychol. 1997, 17, 33-45. [CrossRef]

36. Peacock, A.; Rizzo, I. The Heritage Game. Economics, Policy and Practice; Oxford University Press: Oxford, UK, 2008.

37. Wu, S.R.; Fan, P.; Chen, J. Incorporating Culture Into Sustainable Development: A Cultural Sustainability Index Framework for Green Buildings. Sustain. Dev. 2016, 24, 64-76. [CrossRef]

38. Throsby, D. Economics and Culture; Cambridge University Press: Cambridge, UK, 2001.

39. Graham, B.; Howard, P. Heritage and Identity; Ashgate: Aldershot, UK; Burlington, VT, USA, 2008.

40. Murzyn-Kupisz, M. Barbarzyńca w ogrodzie? Dziedzictwo kulturowe widziane z perspektywy ekonomii. Zarzadzanie Publiczne 2010, 3, 19-32.

41. Purchla, J. Dziedzictwo kulturowe a kapitał społeczny. In Dlaczego i jak w Nowoczesny Sposób Chronić Dziedzictwo Kulturowe? Rottermund, A., Ed.; Polski Komitet do spraw UNESCO: Warszawa, Poland, 2014; pp. 21-30.

42. Gaweł, Ł. Zarządzanie strategiczne szlakiem dziedzictwa kulturowego w świetle koncepcji stakeholders. Turystyka Kulturowa 2012, 10, 31-40.

43. Gaweł, Ł. Szlaki Dziedzictwa Kulturowego: Teoria i Praktyka Zarzadzania; Wydawnictwa Uniwersytetu Jagiellońskiego: Kraków, Poland, 2011.

44. Makuc, N. THETRIS transnational church route: Valorisation of sacral cultural heritage for fostering development of rural areas. Annales 2015, 25, 585-594. 
45. Terzić, A.; Bjeljac, Ž.; Jovičić, A.; Penjišević, I. Cultural Route and Ecomuseum Concepts as a Synergy of Nature, Heritage and Community Oriented Sustainable Development. Eur. J. Sustain. Dev. 2014, 3, 1-16. [CrossRef]

46. Birkeland, I. The potential space for cultural sustainability: Place narratives and place-heritage in Rjukan. In Theory and Practice in Heritage and Sustainability: Between Past and Future; Auclair, E., Fairclough, G., Eds.; Routledge: New York, NY, USA, 2015; pp. 161-175.

47. Gražulevičiūtė, I. Cultural Heritage in the Context of Sustainable Development. Environ. Res. Eng. Manag. 2006, 3, 74-79.

48. Mikos von Rohrscheidt, A. Kulturowe szlaki turystyczne-Próba klasyfikacji oraz postulaty w zakresie ich tworzenia i funkcjonowania. Turystyka Kulturowa 2008, 2, 17-31.

49. Stasiak, A. Produkt turystyczny—Szlak. Turystyka i Hotelarstwo 2006, 10, 11-13.

50. Bogacz-Wojtanowska, E.; Gaweł, Ł.; Góral, A. (Eds.) Szlaki Kulturowe jako Medium Zmian w Kulturze; Stowarzyszenie Gmin i Powiatów Małopolski: Kraków, Poland, 2016.

51. Góral, A. Zarządzanie dziedzictwem-O paradoksie planowania przeszłości. In Etnografie Instytucji Dziedzictwa Kulturowego; Gaweł, Ł., Kostera, M., Eds.; Wydawnictwo Uniwersytetu Jagiellońskiego: Kraków, Poland, 2018; pp. 177-188.

52. Provan, K.G.; Lemaire, R.H. Core concepts and key ideas for understanding public sector organizational networks: Using research to inform scholarship and practice. Public Admin. Rev. 2012, 72, 638-648. [CrossRef]

53. Bugdol, M. Gry i Zachowania Nieetyczne w Organizacji; Difin: Warszawa, Poland, 2007.

54. Rotter, J.B. Interpersonal trust, trustworthiness and gullibility. Am. Psychol. 1980, 35, 1-7. [CrossRef]

55. Gambetta, D. (Ed.) Can we trust trust? In Trust: Making and Breaking Cooperative Relations; Basil Blackwell: New York, NY, USA, 1988; pp. 213-237.

56. Lewicki, R.; Bunker, B.B. Developing and maintaining trust in work relations. In Trust in Organizations; Kramer, R., Tyler, T., Eds.; Sage: Newbury Park, CA, USA, 1996; pp. 114-139.

57. Pillutla, M.M. Trust. In Blackwell Encyclopedic Dictionary of Organizational Behavior; Nicholson, N., Ed.; Wiley-Blackwell: Hoboken, NJ, USA, 2005; p. 1.

58. Mayer, R.C.; Davis, J.H. The Effect of the Performance Appraisal System on Trust for Management: A Field Quasi-Experiment. J. Appl. Psychol. 1999, 84, 123-136. [CrossRef]

59. Prusak, L.; Cohen, D. How to Invest in Social Capital. Harv. Bus. Rev. 2001, 79, 86-93.

60. Weber, M.J.; Deepak, M.; Murnighan, K.J. Normal Acts of Irrational Trust: Motivated Attributions and the Trust Development Process. Res. Organ. Behav. 2005, 2, 75-101. [CrossRef]

61. Sztompka, P. Zaufanie Fundamentem Społeczeństwa; Znak: Kraków, Poland, 2007.

62. Kis, N. The Role and Impact of Trust on the Operation and Sustainability of the State. Public Financ. Q. 2018, 63, 289-302.

63. Xiong, L.; Tang, B.; Xu, K.; Wu, G. Risk Awareness of Interpersonal Trust and Entrepreneurship in China: Evidence from Survey Data. Emerg. Mark. Financ. Trade 2018, 54, 2278-2295. [CrossRef]

64. Guiso, L.; Sapienza, P.; Zingales, L. Trusting the stock market. J. Financ. 2008, 63, 2557-2600. [CrossRef]

65. Smith, G.A.; Stevenson, R.B. Sustaining Education for Sustainability in Turbulent Times. J. Environ. Educ. 2017, 48, 79-95. [CrossRef]

66. Underwood, D.A.; Friesner, D. Asset Mapping, the Social Fabric Matrix, Economic Impact Analysis, and Criteria for Sustainability and Justice: Operational Elements for Holistic Policy Planning. J. Econ. Issues 2017, 51, 813-827.

67. Frerichs, L.; Kim, M.; Dave, G.; Cheney, A.; Hassmiller Lich, K.; Jones, J.; Young, T.L.; Cene, C.W.; Varma, D.S.; Schaal, J.; et al. Stakeholder Perspectives on Creating and Maintaining Trust in Community-Academic Research Partnerships. Health Educ. Behav. 2017, 44, 182-191. [CrossRef]

68. Chi Kwan, N.; D'Souza, C. Categorizing "Others": The Segmentation of Other Actors for "Faith in Others' Efficacy (FIO). In Proceedings of the International Conferences ITS, ICEduTech and STE, Melbourne, Australia, 6-8 December 2016; pp. 301-305.

69. Abrego, C.; Pankake, A. The District-Wide Sustainability of a Professional Learning Community during Leadership Changes at the Superintendency Level. Admin. Issues J. Educ. Pract. Res. 2011, 1, 3-13. [CrossRef]

70. Almers, E. Pathways to Action Competence for Sustainability-Six Themes. J. Environ. Educ. 2013, 44, 116-127. [CrossRef] 
71. Hynie, M.; MacNevin, W.; Prescod, C.; Rieder, B.; Schwartzentruber, L. The Morning After: Stakeholder Reflections on the Sustainability of a Community-Campus Engagement Center in the Changing Environment. Metrop. Univ. 2016, 27, 27-46.

72. Gilbert, D.R.; Stoner, J.A.F.; Freeman, E.R. Kierowanie; Polskie Wydawnictwo Ekonomiczne: Warszawa, Poland, 2001.

73. Koźmiński, A. Koniec Świata Menedżerów; Wydawnictwa Akademickie i Profesjonalne: Warszawa, Poland, 2008.

74. Dong, W.; Han, H.; Ke, Y.; Chan, K.C. Social Trust and Corporate Misconduct: Evidence from China. J. Bus. Ethics 2018, 151, 539-562. [CrossRef]

75. Downs, C. Networks, trust, and risk mitigation during the American Revolutionary War: A case study. Econ. Hist. Rev. 2017, 70, 509-528. [CrossRef]

76. Klijn, E.-H.; Edelenbos, J.; Steijn, B. Trust in governance networks: Its impacts on outcomes. Admin. Soc. 2010, 42, 193-221. [CrossRef]

77. Bevelander, D.; Page, M.J. Ms. Trust: Gender, Networks and Trust - Implications for Management and Education. Acad. Manag. Learn. Educ. 2011, 10, 623-642. [CrossRef]

78. Palmer, A.; Huo, Q. A study of trust over time within a social network mediated environment. J. Mark. Manag. 2013, 29, 1816-1833. [CrossRef]

79. Hakanen, M.; Häkkinen, M. Management possibilities for interpersonal trust in a business network. Nord. J. Bus. 2015, 64, 249-265.

80. Orman, L. Information markets over trust networks. Electron. Commer. Res. 2016, 16, 529-551. [CrossRef]

81. Jiang, W.; Wang, G.; Bhuiyan, M.Z.A.; Wu, J. Understanding Graph-Based Trust Evaluation in Online Social Networks: Methodologies and Challenges. ACM Comput. Surv. 2016, 49, 1-35. [CrossRef]

82. Kastberg, G. Trust and Control in Network Relations: A Study of a Public Sector Setting. Financ. Account. Manag. 2016, 32, 33-56. [CrossRef]

83. Hansen, T. The Virtuous Cycle of Social Support and Trust in Network Facilitation. Group Facil. Res. Appl. J. 2016, 13, 5-15.

84. Awaworyi Churchill, S.; Mishra, V. Trust, Social Networks and Subjective Wellbeing in China. Soc. Indic. Res. 2017, 132, 313-339. [CrossRef]

85. Tasselli, S.; Kilduff, M. When Brokerage Between Friendship Cliques Endangers Trust: A Personality-Network Fit Perspective. Acad. Manag. J. 2018, 61, 802-825. [CrossRef]

86. Riyanto, Y.E.; Jonathan, Y.X.W. Directed trust and trustworthiness in a social network: An experimental investigation. J. Econ. Behav. Organ. 2018, 151, 234-253. [CrossRef]

87. Zhou, L.; Su, C.; Sun, X.; Zhao, X.; Choo, K.-K.R. Stag hunt and trust emergence in social networks. Future Gener. Comput. Syst. 2018, 88, 168-172. [CrossRef]

88. Marineau, J.E. Trust and Distrust Network Accuracy and Career Advancement in an Organization. Group Organ. Manag. 2017, 42, 487-520. [CrossRef]

89. Velimirovic, J.D.; Janjic, A.; Velimirovic, L.Z. Modelling electronic trust using bayesian networks. In Proceedings of the International May Conference on Strategic Management, Bor, Serbia, 25-27 May 2018; pp. 460-465.

90. Pratono, A.H. From social network to firm performance. Manag. Res. Rev. 2018, 41, 680-700. [CrossRef]

91. Beilmann, M.; Kööts-Ausmees, L.; Realo, A. The Relationship Between Social Capital and Individualism-Collectivism in Europe. Soc. Indic. Res. 2018, 137, 641-664. [CrossRef]

92. Lee, J.H.; Tamraker, C. The Effects of Network Characteristics and Social Capital on Organizational Performance: The Mediated Effect of Information Sharing. J. Mark. Thought 2018, 5, 14-29.

93. von Friedrichs Grangsjo, I.; Gummesson, E. Hotel networks and social capital in destination marketing. Int. J. Serv. Ind. Manag. 2006, 17, 58-75. [CrossRef]

94. Agheorghiesei, N.; Nita, V. Networks and social capital-important advantages for entrepreneurs in tourism. Revista de Turism 2009, 7, 10-19.

95. Hitchcock, M.; Wesner, S. Vietnamese values, networks and family businesses in London. Asia Pac. Bus. Rev. 2009, 15, 265-282. [CrossRef]

96. Holladay, P.J.; Powell, R.B. Resident perceptions of social-ecological resilience and the sustainability of community-based tourism development in the Commonwealth of Dominica. J. Sustain. Tour. 2013, 21, 1188-1211. [CrossRef] 
97. Barrutia, J.M.; Echebarria, C. Factors affecting the attitude of tourism-destination local authorities towards sustainable planning tools in a networking context: The Balearic Sustainability Network. J. Sustain. Tour. 2015, 23, 207-233. [CrossRef]

98. Koens, K.; Rhodri, T. Is small beautiful? Understanding the contribution of small businesses in township tourism to economic development. Dev. South. Afr. 2015, 32, 320-332. [CrossRef]

99. Lin, H.F. Determinants of successful virtual communities: Contributions from system characteristics and social factors. Inf. Manag. 2008, 45, 522-527. [CrossRef]

100. Staniulienè, S. Research of trust in virtual network relationships: The case of tourism sector. Manag. Organ. Syst. Res. 2016, 76, 119-131.

101. Polat, S.; Aktas Polat, S. Turizmde Önde Gelen Ülkelerde Normlar, Güven ve Sosyal Ağlar Temelinde Sosyal Sermaye. J. Admin. Sci. 2016, 14, 385-413.

102. Balińska, A. Sieciowe produkty turystyczne jako przykład przedsiębiorczości na obszarach wiejskich. Turystyka i Rozwój Regionalny 2017, 8, 5-14. [CrossRef]

103. Czernek, K. Zakorzenienie społeczne jako stymulanta zaufania w kooperacji przedsiębiorstw turystycznych. Organizacja i Kierowanie 2017, 2, 199-213.

104. Kosmaczewska, J. Kapitał społeczny mieszkańców wsi jako czynnik turystycznego rozwoju obszarów wiejskich. Acta Sci. Pol. Oeconomia 2009, 8, 87-96.

105. Czakon, W.; Czernek, K. The role of trust-building mechanisms in entering into network coopetition: The case of tourism networks in Poland. Ind. Mark. Manag. 2016, 57, 64-74. [CrossRef]

106. Czakon, W.; Klimas, P. Klimat współpracy międzyorganizacyjnej w diadach i sieciach sektora turystyki. Handel Wewnętrzny 2017, 3, 53-65.

107. Maćkowiak, M.; Graja-Zwolińska, S. Znaczenie zaufania w budowaniu współpracy sieciowej w turystyce wiejskiej. In Sieci Wspótpracy w Turystyce Wiejskiej. Stan Obecny i Nowe Wyzwania; Wojciechowska, J., Ed.; Wydawnictwo Uniwersytetu Łódzkiego: Kraków-Łódź, Poland, 2017; pp. 57-70.

108. Eisenhardt, K.M. Building Theories from Case Study Research. Acad. Manag. Rev. 1989, 14, 532-550. [CrossRef]

109. Stake, R.E. Qualitative Case Studies. In Qualitative Research, 3rd ed.; The Sage Publications: Thousand Oaks, CA, USA, 2005; pp. 443-467.

110. Yin, R. Case Study Research; Sage Publications: Beverly Hills, CA, USA, 1984.

111. Kostera, M. Postmodernizm w Zarzadzaniu; Polskie Wydawnictwa Ekonomiczne: Warszawa, Poland, 1996.

112. Stake, R. The Art of Case Study Research; The Sage Publications: Thousand Oaks, CA, USA, 1995.

113. Agranoff, R.; McGuire, M. Big Questions in Public Network Management Research. J. Public Admin. Res. Theory 2001, 11, 295-326. [CrossRef]

114. Kennis, P.; Provan, K.G. Towards an exogenous theory of public network performance. Public Admin. 2009, 87, 440-456. [CrossRef]

115. McGuire, M. Collaborative public management: Assessing what we know and how we know it. Public Admin. Rev. 2006, 66, 33-43. [CrossRef]

116. Craig, D.; Porter, D. The Third Way and The Third World: Poverty Reduction and Social Inclusion Strategies in The Rise of “Inclusive" Liberalism. Rev. Int. Political Econ. 2004, 11, 387-423. [CrossRef]

117. Lowenthal, D. The Heritage Crusade and the Spoils of History; CUP: Cambridge, UK, 1998.

118. Misztal, B.A. Trust in Modern Societes; Polity: Oxford, UK, 1996.

119. Sztompka, P. Socjologia. Analiza Społeczeństwa; Znak: Kraków, Poland, 2012.

120. Nederhand, J.; Bekkers, V. Self-organization and the role of government. How and why does self-organization evolve in the shadow of hierarchy? Public Manag. Rev. 2016, 18, 1063-1084. [CrossRef]

121. Huggins, R. Forms of network resource: Knowledge access and role of inter-firm networks. Int. J. Manag. Rev. 2010, 12, 335-352. [CrossRef]

122. Korczynski, M. The Political Economy of Trust. J. Manag. Stud. 2000, 37, 1-21. [CrossRef]

123. Robbins, S.P.; DeCenzo, D.A. Podstawy Zarządzania; PWE: Warszawa, Poland, 2002.

124. Pilarska, A. Wokół pojęcia poczucia tożsamości: Przegląd problemów i propozycja konceptualizacji. Nauka 2016, 2, 123-141.

125. Mariotti, F; Haider, S. Networks of practice' in the Italian motorsport industry. Techno. Anal. Strateg. Manag. 2018, 30, 351-362. [CrossRef] 
126. Dominguez, N.; Mayrhofer, U.; Obadia, C. The antecedents of information exchange in export business networks. Management 2017, 20, 463-488.

127. Thévenard-Puthod, C.; Picard, C. L'influence du profil du dirigeant sur le nombre et la forme des réseaux interentreprises dans l'artisanat. Rev. Int. PME 2013, 26, 187-212. [CrossRef]

128. Yushi, J.; Naqvi, M.H.A.; Naqvi, M.H. Using Social Influence Processes and Psychological Factors to Measure Pervasive Adoption of Social Networking Sites: Evidence from Pakistan. Emerg. Mark. Financ. Trade 2018, 54, 3485-3499. [CrossRef]

129. Andruszkiewicz, M. Problemy etyki słowa w państwie prawa. In Filozoficzne $i$ Teoretyczne Zagadnienia Demokratycznego Państwa Prawa; Kosikowski, C., Ed.; Wydawnictwo Temida 2: Białystok, Poland, 2015; pp. 15-28.

130. Breczko, A. Wielokulturowość jako źródło dylematów moralnoprawnych w demokratycznym państwie prawa. In Filozoficzne i Teoretyczne Zagadnienia Demokratycznego Państwa Prawa; Kosikowski, C., Ed.; Wydawnictwo Temida 2: Białystok, Poland, 2015; pp. 29-44.

131. Oliwniak, S. Giorgio Agamben o prawach człowieka we współczesnym demokratycznym państwie prawa. In Filozoficzne i Teoretyczne Zagadnienia Demokratycznego Państwa Prawa; Kosikowski, C., Ed.; Wydawnictwo Temida 2: Białystok, Poland, 2015; pp. 101-114.

132. Ambrose, M.L.; Schminke, M. Organization Structure as a Moderator of the Relationship Between Procedural Justice, Interactional Justice, Perceived Organizational Support, and Supervisory Trust. J. Appl. Psychol. 2003, 88, 295-305. [CrossRef]

133. Saunders, M.; Thornhill, A. Trust and mistrust in organizations: An exploration using an organizational justice framework. Eur. J. Work Organ. Psychol. 2004, 13, 493-515. [CrossRef]

134. Stinglhamber, F; De Cremer, D.; Mercken, L. Perceived Support as a Mediator of the Relationship Between Justice and Trust. Group Organ. Manag. 2006, 31, 442-468. [CrossRef]

135. Blackburn, S. Oksfordzki Słownik Filozoficzny; Książka i Wiedza: Warszaw, Poland, 1994.

136. Goo, J.; Huang, C.D. Facilitating relational governance through service level agreements in IT outsourcing An application of the commitment-trust theory. Decis. Support Syst. 2008, 46, 216-232. [CrossRef]

137. Tan, H.H.; Lim, A.K. Trust in Coworkers and Trust in Organizations. J. Psychol. 2009, 143, 45-66. [CrossRef] [PubMed]

138. Vidotto, G.; Vicentini, M.; Argentero, P.; Bromiley, P. Assessment of Organizational Trust: Italian Adaptation and Factorial Validity of the Organizational Trust Inventory. Soc. Indic. Res. 2008, 88, 563-575. [CrossRef]

139. Czakon, W. Istota relacji sieciowych przedsiębiorstwa. Przeglad Organizacji 2005, 9, 9-13.

140. Morgan, R.; Hunt, S.D. The Commitment-Trust Theory of relationship marketing. J. Mark. 1994, 58, $20-38$. [CrossRef]

141. Hardin, G. The tragedy of the commons. Science 1968, 162, 1243-1248. [PubMed]

142. Burt, R.S. Brokerage and Closure. An Introduction to Social Capital; Oxford University Press: Oxford, UK, 2005.

143. Macneil, I.R. Contracts: Adjustment of long term economic relations under classical, neoclassical and relational contract law. Northwest. Univ. Law Rev. 1978, 72, 854-905.

144. Macneil, I.R. The New Social Contract; Yale University Press: New Haven, CT, USA, 1980.

(C) 2019 by the authors. Licensee MDPI, Basel, Switzerland. This article is an open access article distributed under the terms and conditions of the Creative Commons Attribution (CC BY) license (http://creativecommons.org/licenses/by/4.0/). 